Journal of Social Sciences 3 (4): 172-175, 2007

ISSN 1546-9239

(C) 2007 Science Publications

\title{
A Story and a Belief in Spirit of Phoo (Grandpa) Loop : An Access to Resources of Fishermen at the Ubon Rattana Dam, Khon Kaen, Thailand
}

\author{
${ }^{1}$ Wichian Mibun ${ }^{1}$ chayan Vaddhanaphuti ${ }^{2}$ Somsak Srisontisuk and ${ }^{3}$ chusak Wittayapak \\ ${ }^{1}$ Faculty of Humannities and Social Sciences, Mahasarakham University, 44150, Thailand \\ ${ }^{2}$ Faculty of Humannities and Social Sciences, Khon Kaen University, Khon Kaen, 44002, Thailand \\ ${ }^{3}$ Faculty of Social Sciences Chiang Mai University, Chiang Mai, 5002, Thailand
}

\begin{abstract}
The purposes of the article were twofold. 1. To bring a belief in spirit to gain an access to resources. 2. To propose a working model of and adapting method for utilizing resources of fishermen at the Ubon Rattana Dam. The documentary and field data were collected using participant observations and in-depth interviews. The theory of access was used to analyze the data. The research results were as follows: The access to resources of the fishermen at the Ubon Rattana Dam, shown in Fig 1. was based on a belief in the spirit of Phoo Loop shown in Fig 2. The spirit was held highly as a local hero among the ethnic Thai-Lao people. The belief was used as a thinking basis for making a dynamic and strategic access to resources. Spirit houses of Phoo Loop, as a symbolic negotiator, were built near the Dam. The houses also signified power over the land and ideological negotiation using folk songs narrating how respectful Phoo Loop, a local power, was. Rum ours due to various accidents occurred in the area were also used to scare people as well as put more confidence in the spirit and practically gain an access to resources of the fishermen.
\end{abstract}

Key words: A story, belief, spirit of Phoo Loop, resources, fishermen at the Ubon Rattana Dam

\section{INTRODUCTION}

Becoming fishermen at the Ubon Rattana Dam, took place in 1966, was quite new for most farmers who lived near the newly built dam and whose farm land areas were taken away by the dam's water-shade. Currently, there were about 4,870 fishing families residing in 103 villages. The fishing profession for the fishermen experienced a crisis in 1995. The fish in the dam as a whole decreased quite drastically due to ecological changes and heavy fishing. As the Fishing Department, the Ministry of Agriculture and Cooperative sapped in order to re-in force the existed law to prevent heavy fishing, conflicts between the government and the fishermen arose; the fishermen were prevented from accessing fishing resources. It was the first time for those fishermen to ally against the government authority. They forced into the fishing areas in order to get fish for their survival. The waiter intended to use a belief in the spirit of Grandpa Loop to indicate an adaptation for accessing the fishing resources using various strategies under environmental, socio-economic, political and cultural contexts. The conceptual framework was the theory of access ${ }^{[3]}$. The given theory was based on the idea concerning the ability to gain an access to resources ${ }^{[4]}$. The ability was meant power to run priorities for social interactions so that people were forced or given opportunity to gaining an access to resources rather than gaining some asset relations alone. Gaining an access to resources was based on practical uses and relations between power, power groups and power-network and asset using social relation criterions, such as money, technology, markets, knowledge, power labor, social identity, and bargains. The method used was qualitative. The data collected included documentary and field studies. The field work was done using participant observations, surveys, and in depth-interviews. The writer observed the ecological system surrounded the dam participated rituals that offered food and respect to the spirit. He also carried out in depth-interviews inquiring thinking and belief about the spirit of Phoo Loop. He then analyzed the collected data under the social, economic, cultural, political, and administrative contexts and the roles of social grouping related to the spirit. The story of Phoo Loop spirit: A local hero of the ethnic Thai-Lao people.

The story of Phoo Loop spirit was told differently in each geographical area. As for the people at the Ubon Rattana Dam, the spirit of Phoo Loop was depicted as a hunter and lived at Phu Phan Kham, the

Corresponding Author: Wichian Mibun, Faculty of Humannities and Social Sciences, Mahasarakham University, Mahasarakham, 44150, Thailand. 
area the Dam was built. On day the hunter Loop followed the footprints of deer into a deep jungle. He found a large pond situated near a mountain creek. There were a lot of fish in the pond. He changed his mind to catch fish instead. He built a dike across the mouth of the creek in order to empty the pond. He tried and tried but could not drain off the water. $\mathrm{He}$ wondered if something underneath was preventing the drainage. He decided to make a few dives into the pond. To his surprise he saw a water-ghost who made a large hole connecting the creek and the pond. The hunter fought with the ghost and finally the ghost was chased away from the area. He then sealed off the hole, emptied the pond, and caught the fish he wanted. Since then every time the fishermen went to catch fish at the Ubon Rattana Dam they asked Grandpa Loop spirit for help. However, people at different locations had their own version of the story depending upon objectives. From this point of view, the spirit of Phoo Loop did not belong to a specific clan; he was a local hero for the ethnic Thai-Lao people. The belief in the spirit of Phoo Loop of the Thai-Lao people. The belief in such a supernatural being began in the Lan Chang period. The spirit houses of Phoo Loop were put up near or around the entrance to the Dam. The first one was at a roadside between Amphoe Ubon Rattana-Nonsang. It was then followed by the ones at the Regional Electric Generating Unit, the Ubon Rattana market, the Ubon Rattana Fishing Prevention and Control Unit, at Doi Wiwek-tham (Nam Pong National Park), and behind Phu Phan Kham Mountain Ranges. The Spirit of Luang Phoo Loop: A Symbolic Bargaining. The Ubon Rattana Dam was built between the meeting points of 2 mountain ranges. One was Hua Phu Phan, the other was Hua Phu Phan Kham. The area was known as "Phong Neeb" The Phong River went through the area. After the completion of the Dam the Regional Electric Generating Unit had put a large Buddha Image (Luang Phoo Kaow) at Hua Phu Phan Kham and phoo Loop (Grandpa Loop) at Hua Phu Phan. In 1999 the Thailand Electric Generating Authority put up a Buddha Image, known as Phra Buddha Sirisattarat (Luang Phor Jed Kasat) near Phoo Loop. The people in the area did not agree with such an idea but they could not do anything about it. As a tractor driver was preparing a road leading to Pha Kham where the spirit house of Phoo Loop was standing, a large boulder ran over the tractor killing its driver. From the people's point of view, the accident took place was due to the un respectful ness of the authority personnel toward the spirit of Phoo Loop. Since then the people and authority personnel paid more respect to the spirit. The author looked at the given situation as an attempt of the authority to gain power over social and physical contexts using the Buddhist Symbols. Instead of being controlled by such an attempt, the people who lived around the Dam paid even more respect to the spirit. They chose a variety of ways to approach the spirit. One of such strategies was to use the fatal accident as a precaution not to overlook the existence of the spirit of Phoo Loop. The erection of the Phoo Loop spirit houses indicated symbolic bargaining power between superiors and subordinates. The spirit houses, food and various kinds of offerings were part of such power. As for the authority, the erected spirit house of Phoo Loop was kept inside the official land area and fewer people could approach and give their respect. As for the spirit houses erected elsewhere people could pay respect and offer food and others as often as they wanted.

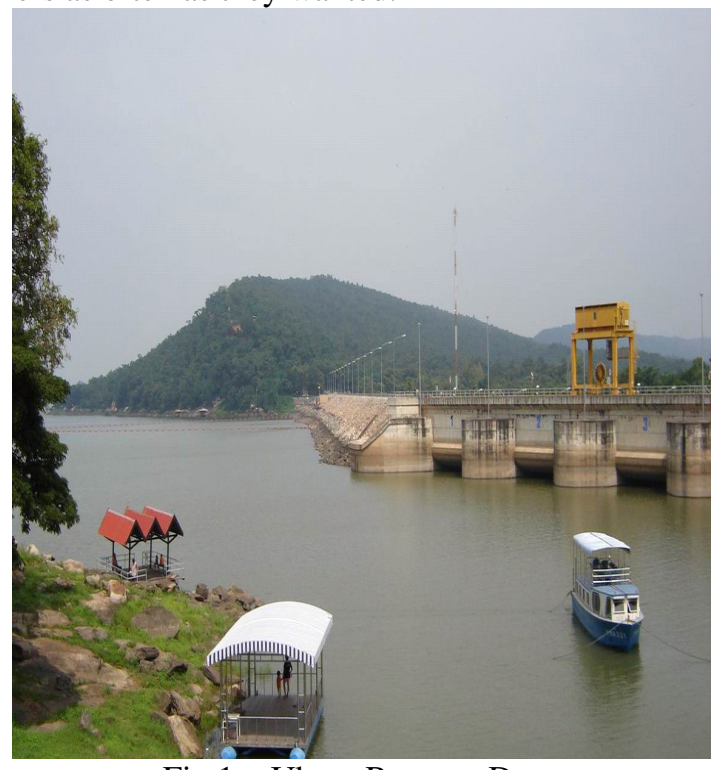

Fig.1: Ubon Rattana Dam

The spirit of Phoo Loop : An ideological bargaining A story of Phoo Loop's spiritual power told by the people around the Dam, being done continuously, was seen as attempts to show as well as advise how respectful the power of the spirit was. Mr. Pao, a fisherman there, once told the writer, "Phoo Loop was believed to own everything - trees, wild animals and fish. Whoever wants any of them needs to ask for his permission first. His power cannot be abolished or tampered with. When the fishermen ran into problems while fishing, such as, strong wind or rain, they often asked protection from the spirit". The writer did just that several times. Mo Lam : Performing art and claiming right over geographical land area of spirit of Luang Phoo Loop. Mo lam, a performing art of the ethnic Thai-Lao, 
presented a whole range of stories, such as, the Buddhist teachings, religions, love, history, way of life, social events, and entertainment. In Isan, mo lam of all types often stepped in time of crises and offered a way

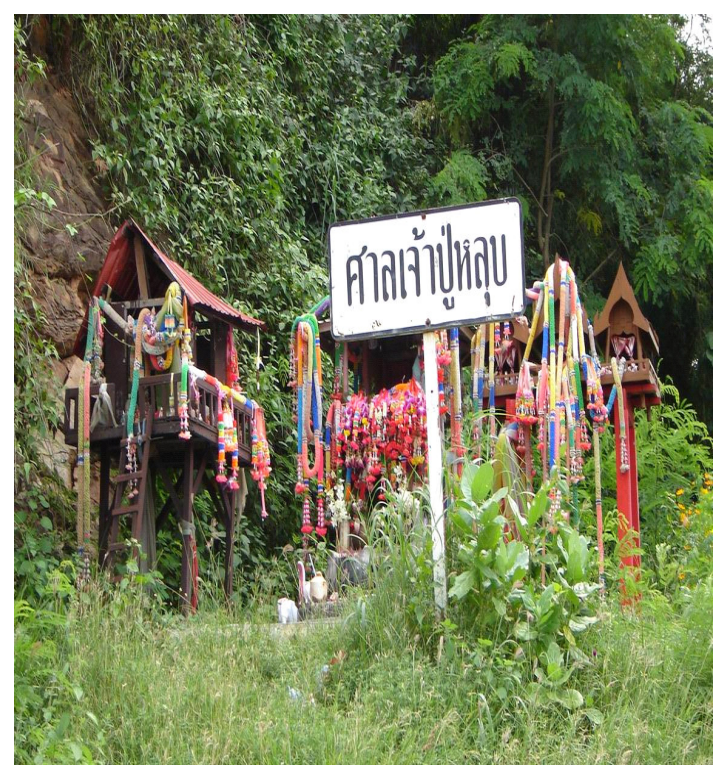

Fig.2: Phoo Loop at Ubon Rattana Dam

they all presented in folk singing or speeches. Molam onchan presented the problems that arose from the dam construction. Mo Lam Prommar, another Isan folk singer, composed one of his songs (klon lam) on a ghost law in Isan. In this given law, the spirit of Loop was supposed to be the most highly respected among the ethnic Thai-Lao in the northern Isan area. The spirits of all kinds were believed to reside at the villages and provinces protecting rice fields, villages, and the provinces. The spirit of Phoo Loop was believed to reside and provide protection at the regional level. The content of such a composed folk song or klon lam showed a local attempt of administrative power using ghosts or spirits as key symbolic figures. Such strategies_were used practically and ideologically to bargain with the government power. The story of Phoo Loop implied or carried 2 meanings. First, the spirit of Phoo Loop was repeatedly used or meant to indicate the long lasting and existence of the spirit and to scare the government officials who worked in the area. Second, under the spirit of Phoo Loop, the fishermen and government officials were locally, regionally, and mutually forced to work together. Phoo Loop : A practical bargain People of all accupations in the Dam area all paid highly respect to the spirit of Phoo Loop. The announcement of the Department of Fishery on the fish conservation area at Ban Tha Rua some years back drew a serious confrontation between the government officials and fishermen. The fishermen at Ban Tha Rua could not take their fishing boats out for fishing due to the strict rules of the authority. They often got caught trespassing the restricted fish conservation areas. The fishermen sometimes secretly cut the barricade marking lines. The fishermen and villagers constructed a spirit house, as a symbol of Phoo Loop near the entrance of the Prevention and Control Fresh water Fishery, Ubon Rattana Dam. The fishermen and villagers then took their turn to ask for protection and favor from the spirit. They also went forward to the spirit house with offerings, such as, folwers, scents, candles, and wreaths To put more emphasis their practieal bargain, the fishermen often made up rumors of Phoo Loop's credible miracles or spiritual power.

The story of Phoo Loop at the Ubon Rattana Dam was similar to Tambiah's finding that guardian spirits were believed to own the village or the whole pieces of land. ${ }^{[6]}$ found that the people fully paid respect to the spirit of Chao Pho Srinakhon Tao because of the belief that the being owned the land area. ${ }^{[1]}$ also found that natives of Zimbabwe used discourses to create meanings and memory in order to put forward the traditional right over the woodland where the White people had already taken over. Their main reasons for doing that were that their ancestors as well as they themselves gathered and hunted for food and other necessities for living from that woodland long before their country was colonized. ${ }^{[2]}$ supported Fortmann's finding that the natives' social memory based on the role of spiritual beings in their social and cultural activities for making their traditional right over natural resources. The story of Phoo Loop had been applied in various strategies, forms, or methods for gaining rights over natural resources. They could be rumors of spiritual power or miracles; spirit houses erected on the land area where conflicts between the government officials and fishermen arose; local ideology and traditional power were used for composition of folk songs or klon lam ; making similar situations related to Phoo Loop ; and cutting the barricade marking lines of the fish conservation areas. The above practical strategies were based on thinking and belief in supernatural power (spirit) of the fishermen passing down from previous generations. The people made their strategies, forms, or methods possible by integrating various wisdom and knowledge at local and regional levels as well as worldwide so that bargaining power and present day adaptation could be achieved among the fishermen. 


\section{CONCLUSION}

Making the belief in Phoo Loop, a spiritual hero of the ethnic Thai-Lao fishermen as a thinking foundation for gaining an access to natural fishing resources indicated relationship between the fishermen and other social groups. The spiritual power was exercised through actors under various social, economic, environmental, political, cultural contexts, government administration, ideology, folk songs (Klon lam), rum ours, cutting the marking lines of the fish conservation areas, and erecting of spirit houses. Scary stories or accidents occurred in the area were used as bargaining power or building a stronger relationship among the people involved under a belief of the same spirit. However, the access to fishing resources could not be accomplished without an integration of various and dynamic elements under environmental, social, economic, political, and cultural contexts.

\section{ACKNOWLEDGEMENTS}

The authors would like to express their sincere appreciation for all of the support provided.

\section{REFERENCES}

1. Fortmann, L., 1995. Talking Claims Discursive Strategies in contesting property, World Development, 23 : 1045-1064.

2. Moore Donald S., 1993. Contesting Terrain in Zinbabwe's Easthern Highlands Political EcoLogy Ethnography and Peasant Resource Struggles, Economic Geography, pp. 380-401.

3. Ribot C. Jesse., Peluso Nancy lee., 2003. A Theory of Accss, Rural Sociology. pp. 153.

4. Schlager Edella., Ostrom elinor., 1992. Property Rights Regimes and Natural Resources, A Conceptual Analysis, Land Economice, ${ }_{2}$ pp. 249 262.

5. Tambiah, S.J., 1970. Buddihsm and the Spirit Cults in north-east Thailand, Camdridge University Press Uk, pp. 380-401.

6. Thianthaworn, Amasee., 1989. Chao Pho Srinakhon Tao :Role and significance of spirits in N.E., Thailand :A case study at Ban Muarg Tao, Amphoo Payykkaphumpisai, Mahasarakham. 